\title{
Morpho-functional patterns and zonation of South Chilean seaweeds: the importance of photosynthetic and bio-optical traits
}

\author{
Iván Gómez ${ }^{1, *}$, Pirjo Huovinen ${ }^{1,2}$ \\ ${ }^{1}$ Universidad Austral de Chile, Instituto de Biología Marina/Laboratorio Costero de Calfuco, Facultad de Ciencias, \\ Casilla 567, Valdivia, Chile \\ ${ }^{2}$ Centro i mar, Universidad de Los Lagos, Casilla 557, Puerto Montt, Chile
}

\begin{abstract}
We address the question of whether seaweed zonation can be characterized in terms of light absorption, pigmentation, photosynthetic parameters, photoinhibition, and thallus structure. Based on 32 seaweed species from the Pacific coast of southern Chile, intertidal assemblages exhibited higher light requirements for photosynthesis $\left(E_{\mathrm{k}}\right)$ and lower thallus light absorptances than subtidal algae. $E_{\mathrm{k}}$ values were lower than the highest measured irradiances at the corresponding natural depths, suggesting that photosynthesis in these organisms could potentially occur at lower depths. During summer, $1 \%$ of photosynthetically active radiation (PAR) reached a depth of $23 \mathrm{~m}$, while UV$\mathrm{B}$ and UV-A wavelengths were completely attenuated at $<3$ and $6 \mathrm{~m}$, respectively. Overall, the photobiological adaptations were associated with depth, morphology, and taxonomic group. Photoinhibition was similar in algae from different depths, although recovery was higher in upper littoral algae than in infra- and sublittoral species. The characteristics conferring competitive abilities in light use and light stress tolerance were not, or only partially, related to the classical Littler form-function model. The filamentous and foliose forms were able to acclimate rapidly to changing light and physical stress in the supralittoral zone. For infralittoral kelps living in a highly dynamic environment, higher cross-sectional area and enhanced in vivo light absorption were coupled with morphological features (e.g. massive thallus) that are advantageous in withstanding e.g. water movement. By contrast, the rapid physiological adjustments that allow algae to endure solar stress (e.g. photochemical down-regulation) were strongly dependent on the position on the shore but not on gross morphology.
\end{abstract}

KEY WORDS: Absorptance $\cdot$ Bio-optics $\cdot$ PAR $\cdot$ Photosynthetic characteristics $\cdot$ Seaweeds $\cdot$ Southern Chile $\cdot$ Underwater light $\cdot$ UV radiation $\cdot$ Zonation

Resale or republication not permitted without written consent of the publisher

\section{INTRODUCTION}

Marine shorelines are excellent examples of places where variations in physiological traits of organisms (e.g. desiccation tolerance, nutrient uptake, photosynthetic performance, growth) occur across sharp environmental gradients and within a small spatial scale. The structure and function of algae in the context of zonation have been characterized as a complex interplay between abiotic and biotic factors (Underwood 1985, Lüning 1990, Benedetti-Cecchi et al. 2000). As a way of understanding the adaptive features underlying the vertical distribution of seaweeds and their implica- tions for community ecology, various functional-form models based on gross morphology, life history traits, and ecophysiological performance have been proposed (Chapman \& Chapman 1976, Littler \& Littler 1980, Steneck \& Watling 1982). These models were based on the advances in the understanding of the primary strategies of terrestrial plants (Grime 1981) and have also been applied to other macrophyte communities such as seagrasses (Hemminga \& Duarte 2000, Orfanidis et al. 2001, Larkum et al. 2006). In morpho-functional models developed for seaweeds, many of the metabolic attributes have only been inferred and are currently not supported empirically (reviewed by Padilla \& Allen 2000). 
As with terrestrial plants, in which physiological attributes rather than gross morphology define the functional groups (Ackerly \& Reich 1999, Poorter \& Bongers 2006), the light-use characteristics of seaweeds may respond to light adaptations operating across different morphological groups and algal divisions. Dring \& Brown (1982) were among the first to address the physiological basis of seaweed zonation using 4 species from different positions on the shore. These authors indicated that photosynthesis decreased as a function of desiccation stress in all species; however, an effective recovery of photosynthesis after reimmersion was observed only in algae from the upper littoral zones. Further studies focusing on the lightabsorption characteristics, such as optimal thallus optics and light-harvesting capacity, put an emphasis on the internal features of the algae underlying their light adaptations and light-stress tolerance (Ramus 1978, 1981, Dring 1981, Lüning \& Dring 1985, Henley 1993, Markager 1993, Enriquez et al. 1994, Dudgeon et al. 1995, Franklin \& Forster 1997, Bischof et al. 1998). Moreover, morphological characteristics such as canopy structure (e.g. mats) can serve the function of enhancing tolerance to environmental stress, e.g. excessive photodamage in shallow waters (Johansson \& Snoeijs 2002, Raven \& Kübler 2002, Middelboe \& Binzer 2004, Bischof et al. 2006a). Thus, it was recognized that gradients in light availability and the concomitant light requirements for photosynthesis of seaweeds and seagrasses have important morpho-functional implications which can also be studied in the context of zonation (e.g. primary productivity, biomass distribution; Markager \& Sand-Jensen 1992, Dring et al. 1996, Gómez et al. 1997, Johansson \& Snoeijs 2002, Gattuso et al. 2006).

As a result of different biogeographical, oceanographic, and geological processes, seaweed zonation, in terms of the arrangement of the most relevant functional groups (e.g. fucoids, kelps, and canopy-forming species), can vary between locations, and thus a universal scheme applicable to all regions is not realistic (Ingólfsson 2005). At wave-exposed sites in the southeastern Pacific between $25^{\circ}$ and $55^{\circ} \mathrm{S}$, the prevailing zonation patterns are characterized by well delineated seaweed arrangements, i.e. a few species show broad vertical distributions (Santelices 1989). In terms of morpho-functional grouping, algae in this region follow a pattern defined by the presence of sheet-like and filamentous forms at the supralittoral fringe, a midlittoral zone that is dominated by coarsely-branched and thick leathery forms, mainly red algae, a wavebattered infralittoral fringe that is dominated by large kelps (thick leathery) as well as articulated and crustose forms, and a sublittoral zone (up to $7 \mathrm{~m}$ depth) that is characterized by a heterogeneous group of sea- weeds with a relative dominance of thin leathery and sheet-like red algae (e.g. Hymenena, Callophyllis, Laingia; see Huovinen et al. 2007). The ecophysiological foundations underlying these patterns in southeastern Pacific seaweeds are poorly understood. Only recently have some aspects of photosynthetic performance under desiccation stress (Molina-Montenegro et al. 2005), the capacity of photoinhibition (as a photoprotective mechanism; Gómez et al. 2004), and UV stress tolerance (Huovinen et al. 2006, Gómez et al. 2007, Rautenberger et al. 2009) been studied.

The main objective of this study was to examine whether the light requirements and bio-optical properties that seaweeds display across their vertical distribution can be explained using morpho-functional models based on gross morphology. We tested the hypothesis that the light-use characteristics across a depth gradient do not follow the pattern expected based on the classical form-function models (e.g. Littler \& Littler 1980), i.e. at a similar depth, algae from different morpho-functional categories or major taxonomical grouping share similar photobiological characteristics. Through the measurement of a suite of biooptical, morphological, and photosynthetic traits, tolerance to light stress (e.g. enhanced solar UV radiation) at a multi-species level, as well as the underwater light climate, this study provides insights into the photobiological patterns underlying the vertical zonation of seaweeds.

\section{MATERIALS AND METHODS}

Study site. The rocky coast near Valdivia, southern Chile $\left(39^{\circ} 48^{\prime} \mathrm{S}, 73^{\circ} 14^{\prime} \mathrm{W}\right)$ supports an abundant marine flora. The maximum range of the semi-diurnal tides is $2 \mathrm{~m}$. The composition of the main seaweed assemblages found on the sheltered rocky shores of this region has been described previously by Gómez et al. (2004). In the present study, only the most important species from each tidal zone were studied, and thus small branched, epiphytic, encrusting, or scattered species were not included. Representative species of green $(n=6)$, red (19), and brown algae (7) from different morpho-functional groups (sensu Littler \& Littler 1980) were sampled during the summer season, from the 4 different littoral zones, based on the universal scheme of Stephenson \& Stephenson (1972), with some modifications (Table 1): (1) the supralittoral fringe (the upper littoral zone dominated by Porphyra columbina and some filamentous green algae), with an upper limit defined by the extreme high water spring tide (EHWS); (2) the midlittoral zone, dominated by red algae, which extends down to the upper limit of the kelps (e.g. Lessonia); (3) the infralittoral fringe, domi- 
Table 1. Studied seaweeds indicating morpho-functional groups (sensu Littler \& Littler 1980) and depth distribution in the littoral zone on the coast of Valdivia, Chile

\begin{tabular}{|c|c|c|}
\hline Species & Morpho-functional group & Collection depth \\
\hline \multicolumn{3}{|l|}{ Green algae } \\
\hline Chaetomorpha linum (Müller) Kützing & Filamentous & Supra \\
\hline Codium dimorphum Svedelius & Postrate & Mid \\
\hline Ulva linza Linnaeus & Sheet-like (tubular) & Supra-Mid \\
\hline Ulva intestinalis Linnaeus & Sheet-like (tubular) & Supra \\
\hline Ulva lactuca Linnaeus & Sheet-like & Mid \\
\hline Ulva rigida C. Agardh & Sheet-like & Mid \\
\hline \multicolumn{3}{|l|}{ Red algae } \\
\hline Ahnfeltiopsis durvillaei (Bory) Silva \& DeCew & Coarsely branched & Infra \\
\hline Ahnfeltiopsis furcellata (C. Agardh) P.C. Silva \& DeCew & Coarsely branched & Infra \\
\hline Callophyllis variegata (Bory) Kützing & Coarsely branched & Sub \\
\hline Centroceras clavulatum (C. Agardh) Montagne & Filamentous & Mid \\
\hline Ceramium rubrum C. Agardh & Filamentous & Mid \\
\hline Corallina officinalis Linnaeus & Articulate calcareous & Infra \\
\hline Gelidium lingulatum Kützing & Coarsely branched & Mid (pools) \\
\hline Gracilaria chilensis C.J. Bird, McLachlan \& E.C. Oliveira & Coarsely branched & Sub \\
\hline Grateloupia doryphora (Montagne) Howe & Coarsely branched & Infra \\
\hline Laingia hookeri (Lyall ex Harvey) Kylin & Thin leathery & Sub \\
\hline Laurencia chilensis De Toni, Forte \& M.A. Howe & Coarsely branched & Sub \\
\hline Mazzaella laminarioides (Bory) Fredericq & Thick leathery & Mid \\
\hline Nothogenia fastigiata (Bory) P.G. Parkinson & Coarsely branched & Mid \\
\hline Polysiphonia sp. & Filamentous & Mid \\
\hline Prionitis decipiens (Montagne) J. Agardh & Coarsely branched & Sub \\
\hline Porphyra columbina Montagne (shade-type) & Sheet-like & Infra \\
\hline Porphyra columbina Montagne (sun-type) & Sheet-like & Supra \\
\hline Rhodymenia skottsbergii E.Y. Dawson & Coarsely branched & Sub \\
\hline Sarcothalia crispata (Bory) Leisner & Thick leathery & Infra \\
\hline \multicolumn{3}{|l|}{ Brown algae } \\
\hline Colpomenia sinuosa (Roth) Derbis \& Solier & Saccate & Mid \\
\hline Desmarestia ligulata (Stackhouse) Lamouroux & Thick leathery & Sub \\
\hline Durvillaea antarctica (Chamisso) Hariot & Thick leathery & Infra \\
\hline Lessonia nigrescens Bory & Thick leathery & Infra \\
\hline Lessonia trabeculata Villouta \& Santelices & Thick leathery & Sub \\
\hline Macrocystis pyrifera (Linnaeus) C. Agardh & Thick leathery & Infra \\
\hline Scytosiphon lomentaria (Lyngbye) Link & Sheet-like (tubular) & Mid \\
\hline
\end{tabular}

nated by kelps, down to the limit of the extreme low water spring tide (ELWS); and (4) the sublittoral zone (corresponding to the infralittoral zone in the scheme of Stephenson \& Stephenson 1972). The algae from this zone ( $>2 \mathrm{~m}$ ) always remain submerged, and for this study they were collected down to a depth of 2 to $5 \mathrm{~m}$ from the ELWS. It must be emphasized that the subdivisions of the littoral zones represent a complicated semantic field, and other systems currently in use are equally valid (see Lüning 1990 for a comparison). However, we followed the system of Stephenson \& Stephenson (1972) because it adequately describes the physiognomy of the zonation in southern Chile, characterized by 4 well defined zones.

Underwater light measurements. Underwater spectral profiles (300 to $700 \mathrm{~nm}$ ) of solar irradiation were measured in midsummer around solar noon (13:00 to 14:00 h) using the hyperspectral underwater radiometer RAMSES-ACC-UV (Trios Optical Sensors). The attenuation of irradiance with depth in optically homogeneous water follows the law:

$$
E_{\mathrm{d}}(\mathrm{z})=E_{\mathrm{d}}(0) \exp ^{-K_{\mathrm{d}} z}
$$

where $K_{\mathrm{d}}$ is the vertical attenuation coefficient for downward irradiance, $E_{\mathrm{d}}(z)$ is the irradiance at depth $z_{\text {, }}$ and $E_{\mathrm{d}}(0)$ is the irradiance just below the surface (Kirk 1994). $K_{\mathrm{d}}$ values for different wavebands (UV-B: 300315 nm; UV-A: 315-400 nm; photosynthetically active radiation, PAR: $400-700 \mathrm{~nm}$ ) were obtained from the slope of the linear regression of the natural logarithm of measured irradiance versus depth. The log-linear part of the curve was used (fit $r^{2} \geq 0.90$ ). A more detailed characterization of the underwater light field of several sites on the coast of southern Chile has been made by Huovinen \& Gómez (2011).

Photosynthetic activity. In vivo chlorophyll a (chl a) fluorescence of photosystem II (PSII) was measured with a computer-aided portable pulse amplitude modulation fluorometer (PAM-2000, Walz). In order to estimate the electron transport rate (ETR), thallus pieces were put in a dark chamber and irradiated with increasing intensities of PAR (up to $400 \mu \mathrm{mol}$ photon $\mathrm{m}^{-2} \mathrm{~s}^{-1}$ ) provided by the PAM device (Schreiber et al. 1994). ETR was estimated using photosynthesis versus irradiance (P-I) curves by relating the effective quantum yield $\left(\Phi_{\mathrm{PSII}}\right)$ and the actinic irradiance (red-light diode) as follows: 


$$
\mathrm{ETR}=\Phi_{\mathrm{PSII}} \times E_{\mathrm{PAR}} \times A \times 0.5
$$

where $E$ is the incident irradiance of PAR and $A$ is the thallus absorptance (a descriptor of the light absorption capacity of the algae). The factor 0.5 comes from the assumption that 4 of the 8 electrons required to assimilate $1 \mathrm{CO}_{2}$ molecule are supplied by PSII. Absorptance was determined by placing the algae on a cosine corrected PAR sensor (Licor $192 \mathrm{SB}$ ), and then calculating the light transmission as $A=1-E_{\mathrm{t}} / E_{\mathrm{o}}$, where $E_{\mathrm{t}}$ is the irradiance below the alga (transmitted light) and $E_{\mathrm{o}}$ is the incident irradiance. The ETR parameters were defined by fitting a modified version of the non-linear function proposed by Jassby \& Platt (1976):

$$
\mathrm{ETR}=\mathrm{ETR}_{\max } \times \tanh \left(\alpha_{\mathrm{ETR}} \times E_{\mathrm{PAR}} / \mathrm{ETR}_{\max }\right)
$$

where $\mathrm{ETR}_{\max }$ is the maximal ETR, tanh is the hyperbolic tangent function, $\alpha_{\text {ETR }}$ is the efficiency of the electron transport (initial slope of the ETR versus irradiance curves), and $E$ is the incident irradiance. The saturation irradiance for electron transport $\left(E_{\mathrm{k}}\right)$ was calculated as the intercept between $\alpha_{\text {ETR }}$ and the ETR $_{\text {max }}$ values.

Determination of photoinhibition of photosynthesis. Algae, or algal pieces in the case of large thalli (3 to 4 replicates), of the selected species from different depths were exposed to solar radiation in the field from 9:00 to 20:00 h using UV transparent Plexiglas chambers placed just below the water surface in order to allow maximum solar exposure. Chlorophyll fluorescence was measured at different time intervals over the day using the PAM device. Photoinhibition of photosynthesis was calculated as the percentage decrease of the ratio of variable to maximal fluorescence $\left(F_{\mathrm{v}} / F_{\mathrm{m}}\right)$ between the value measured in the morning and minimum value at noon, and the time for recovery in the afternoon was evaluated by comparing the fluorescence with the initial values measured in the morning.

Optical characteristics of algae. Algal samples for the analyses of pigments were blotted dry at the time of sampling and kept frozen $\left(-20^{\circ} \mathrm{C}\right)$ until analysis. Chl $a, b$, and $c$ were extracted in N,N-dimethyl-formamide for $24 \mathrm{~h}$ at $4^{\circ} \mathrm{C}$ in darkness. The pigments were measured using a spectrophotometer and the concentrations determined as fresh weight unit using the dichromatic equations of Inskeep \& Bloom (1985). In situ absorption spectra were measured under natural sunlight by placing blades of algae on the sensor of the radiometer RAMSES.

To determine the area/weight quotient, algae (or in the case of large species, thallus segments) were photographed to scale and weighed. The corresponding surface area was calculated using the software ImagePro Plus 4.55 (Media Cybernetic). Measurements of thallus thickness of the different algal species were made using light microscopy and were done with frozen algal sections stained with the routine hematoxylin-eosin method as described by Gómez et al. (2007).

Statistical treatment. Data were compared using 1-way analysis of variance (ANOVA) followed by the Tukey HSD for unequal $\mathrm{N}$ when differences were detected. ANOVA assumptions (homogeneity of variances and normal distribution) were examined with Bartlett and chi-squared tests. In the case of correlated variables, the data set was submitted to multivariate analysis (MANOVA) with the Wilks' lambda (Rao's R) test as a multivariate $F$. In this case, multivariate homogeneity was tested using Box M, whereas normality was assessed for each dependent variable as in the 1-way ANOVA.

Discriminant analysis was used as an exploratory test of whether the examined photobiological and photosynthetic variables (chlorophyll content, thallus absorptance, thickness, area/weight quotient, ETR max $_{\text {, }}$ $E_{\mathrm{k}}$, and $\alpha$ ) separate algae according to depth, morphofunctional, and taxonomic group. Thus the aim was to determine which variable or suite of variables allows discrimination between different types of algae. Three major analyses were performed, based on depth: supralittoral ( $\mathrm{n}=3$ species), midlittoral (10), infralittoral (10), and sublittoral (5); algal division: green algae (6), red algae (19), and brown algae (7); and morphofunctional group: coarsely-branched (10), sheet-like (7), filamentous (4), and thick-leathery (8). In each case, 3 to 6 replicates for each species were entered. Wilks' lambda and partial Wilks' lambda (ranging from 0 to 1 , where 0 denotes perfect discriminatory power) were used to determine the significance of the model and the individual contribution of each variable to the discrimination between groups, respectively. The analysis was followed by a canonical analysis indicating discriminating coefficients (roots), eigenvalues, cumulative proportion, and score representation of the discriminant functions in order to classify those photosynthetic and bio-optical variables that contribute most to the discrimination between groups. All analyses were performed using the Software Statistica (Stat-Soft).

\section{RESULTS}

\section{Underwater light climate}

Based on the measured $K_{\mathrm{d}}$ values, the study site corresponded to a coastal water type 3 according to Jerlov's (1976) classification. UV-B radiation was attenuated almost completely within the first $2.5 \mathrm{~m}$ of the water column (Fig. 1). In the UV-A region, $99 \%$ attenuation occurred within the upper $6 \mathrm{~m}\left(z_{1} \%\right)$ of the water 


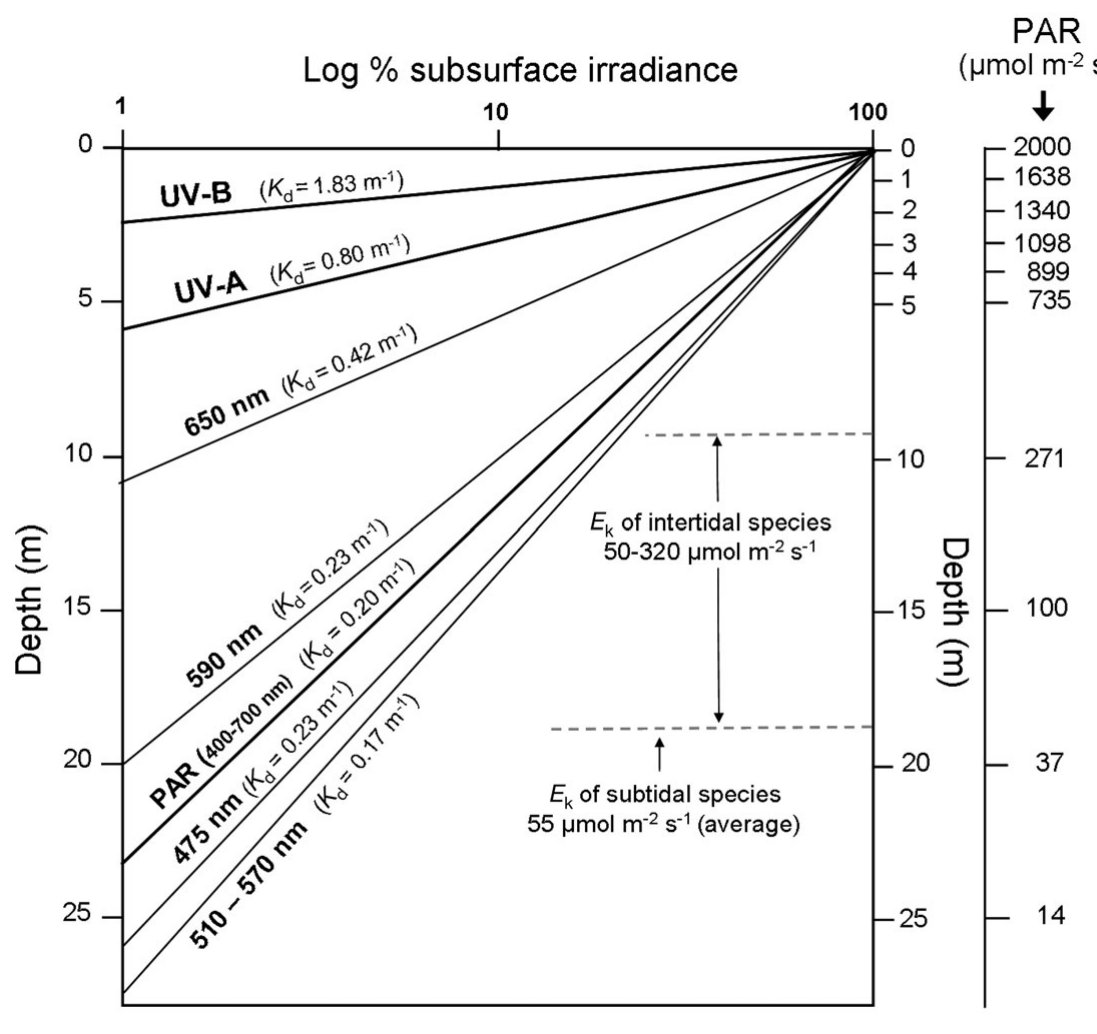

Fig. 1. Underwater solar irradiance in the water column on the Pacific coast of southern Chile, as measured in midsummer (around solar noon) under cloudless conditions with minimal wave action. Penetration depths (as \% of the subsurface irradiance) for UV-B (300-315 nm), UV-A (315-400 nm), and PAR (400-700 nm) and its selected wavelengths. Values represent a mean of 3 to 6 measurements. The vertical attenuation coefficients $\left(K_{\mathrm{d}}\right)$ are given in parentheses. An example of underwater light (PAR) scenario using a surface irradiance of $2000 \mu \mathrm{mol} \mathrm{m}{ }^{-2}$ $\mathrm{s}^{-1}$ is indicated as a reference for depth ranges that set photosynthetic light demands $\left(E_{\mathrm{k}}\right)$ column. The penetration depths $\left(z_{1} \%\right)$ ) for different wavelengths of PAR ranged between 11 and $27 \mathrm{~m}$. Assuming a summer subsurface PAR irradiance of $2000 \mu \mathrm{mol} \mathrm{m} \mathrm{m}^{-2} \mathrm{~s}^{-1}, 67 \%$ remained at a depth of $2 \mathrm{~m}$ (infralittoral fringe during low water). At sublittoral locations, $37 \%$ of averaged PAR remained at a depth of $5 \mathrm{~m}$ (the collection limit of the studied seaweeds), while $1 \%$ reached a depth of $23 \mathrm{~m}$ (Fig. 1).

\section{Exploratory analysis of bio-optical and photosynthetic parameters}

The discriminant analysis was used to examine whether the studied variables $\left(\mathrm{ETR}_{\max }, E_{\mathrm{k}}, \alpha\right.$, chlorophyll content, thallus absorptance, thickness, area/weight quotient) allow the algal groups to be separated (Fig. 2). The discrimination between the 4 depth zones was highly significant (Wilks' lambda $=0.26 ; \quad F_{21,178}=5.08 ; \mathrm{p}<$ $0.00001)$, while the standardized coefficients determined from a canonical representation (Fig. 2A) indicated a higher contribution (82\%) of the first canonical function (CV1), which, according to the standardized coefficients, was marked by the highest contribution of photosynthetic efficiency $(\alpha)$ and thallus thickness (Table 2).
Depth

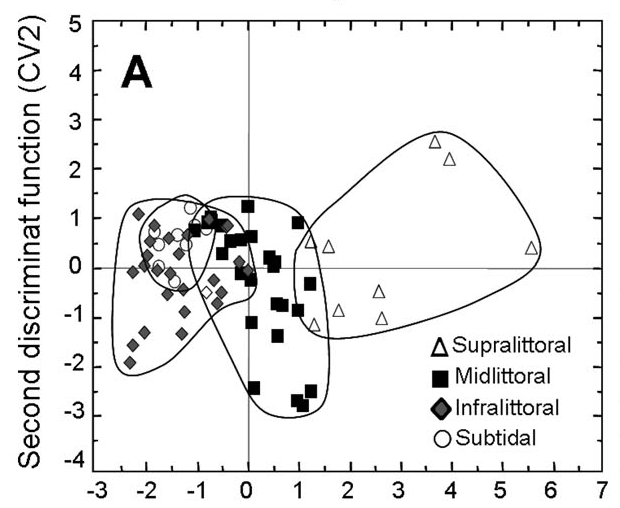

Morpho-functional group

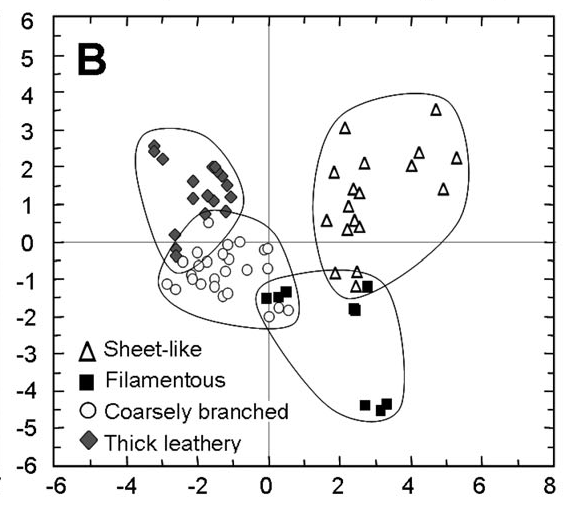

First discriminant function (CV1)
Taxonomic group

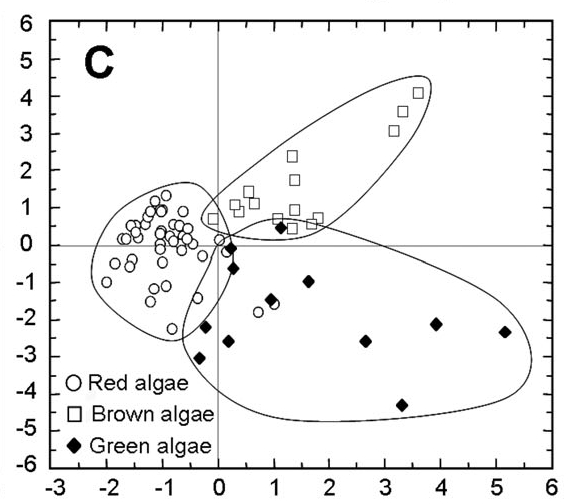

Fig. 2. Discriminant analysis (based on values of maximum electron transport rate, ETR $\mathrm{max}_{\text {i }}$ saturating irradiance point for photosynthesis, $E_{\mathrm{k}}$ p photosynthetic efficiency, $\alpha$; chlorophyll content; thallus absorptance; thickness; area/weight quotient) grouping the algae of the south Pacific coast of southern Chile according to (A) depth zones, (B) morpho-functional categories, and $(\mathrm{C})$ algal divisions 
Similarly, thickness strongly defined the first discriminant function (CV1) separating the supralittoral species (in general characterized by thinner thalli) from the other algal groups (Table 2).

The discrimination in terms of morpho-functional groups was significant (Wilks' lambda $=0.04 ; F_{21,178}=$ $16.67 ; \mathrm{p}<0.00001 ;$ Fig. 2B). In general, the model indicated that the bio-optical variables (chlorophylls, thallus absorptance, area/weight quotients, and thickness) strongly accounted for the overall discrimination, while the photosynthetic variables, with the exception of ETR $\mathrm{Eax}_{\max }$ contributed less. The canonical coefficients indicated that the model clearly separated sheet-like/ filamentous species and the thicker forms. CV1 accounted for $66 \%$ of the discrimination and was weighted principally by chlorophylls, thallus thickness, and the area/weight quotient (Table 2). The second discriminant function (CV2) accounted for $27 \%$ of the total variance and also allowed for a good discrimination between major morpho-functional groups. This function was defined mainly by $\mathrm{ETR}_{\max }$ absorptance, and $E_{\mathrm{k}}$ (Table 2).

The studied parameters successfully discriminated between the major taxonomic groups (Wilks' lambda = $\left.0.19 ; F_{14,126}=11.46 ; \mathrm{p}<0.00001\right)$. The canonical analysis allowed for a good discrimination between the 3 major groups (green, brown, and red algae; Fig. 2C, Table 2). Based on the eigenvalues and cumulative proportions, $56 \%$ of the discrimination was explained by the first canonical function with $\mathrm{ETR}_{\max } E_{\mathrm{k}}$ chlorophylls, and thickness as the variables that best described this function. CV2 also made an important

Table 2. Discriminant analysis results of different depth (4 groups), morphofunctional (4) and taxonomic (3) groupings. Standard coefficients of 2 canonical functions (CV) for 7 photosynthetic and bio-optical variables measured in different seaweed species from the coast of Valdivia (Chile) are indicated. Absolute values of coefficients indicate the contribution of each measured variable to the discriminant function. Eigenvalues and cumulative proportion define the proportion of the each canonical function to the explained variance. Standard statistics and significance of the model (Wilks' lambda) for each analysis is described

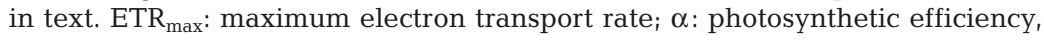
$E_{\mathrm{k}}$ : saturating irradiance point for photosynthesis

\begin{tabular}{|lrrrrrr|}
\hline \multirow{2}{*}{ Measured variable } & \multicolumn{2}{c}{ Depth } & \multicolumn{3}{c}{ Morpho-functional } & \multicolumn{2}{c|}{ Taxonomic } \\
& CV 1 & CV 2 & CV 1 & CV 2 & CV 1 & CV 2 \\
& & & & & & \\
& 0.703 & -0.406 & -0.027 & 1.167 & 0.792 & 2.090 \\
ETR $_{\max }$ & 0.235 & 0.964 & 0.078 & -0.484 & -0.085 & -0.391 \\
$\alpha$ & 0.342 & 0.623 & 0.076 & -0.840 & -0.423 & -1.908 \\
$E_{\mathrm{k}}$ & 0.176 & 0.030 & 0.404 & 0.451 & 1.205 & 0.239 \\
Chlorophylls & -0.152 & -0.496 & -0.002 & -1.074 & -0.147 & 0.195 \\
Absorptance & 0.016 & -0.098 & 0.503 & -0.523 & -0.113 & -0.374 \\
Area/weight quotient & -0.904 & 0.536 & -0.605 & 0.514 & 0.743 & 0.525 \\
Thallus thickness & 1.755 & 0.304 & 4.491 & 1.878 & 1.446 & 1.113 \\
Eigenvalue & 0.824 & 0.967 & 0.661 & 0.936 & 0.564 & 1.000 \\
Cumulative proportion & & & & & &
\end{tabular}

contribution to the whole variance $(44 \%)$ and was mainly weighted by ETR $_{\text {max }}$ chlorophylls, and thallus thickness (Table 2).

\section{Patterns of light requirements for photosynthesis, photoinhibition, and bio-optical properties}

Photosynthesis versus light curves of selected species (Fig. 3) revealed inter-specific differences with a tendency for higher $\mathrm{ETR}_{\max }$ values in algae from the supralittoral zone $\left(46.4 \pm 19.4 \mu \mathrm{mol} \mathrm{e}^{-} \mathrm{m}^{-2} \mathrm{~s}^{-1} ; \mathrm{n}=3\right.$ species), while the lowest values were measured in the sublittoral seaweeds $\left(9.1 \pm 3.6 \mu \mathrm{mol} \mathrm{e}^{-} \mathrm{m}^{-2} \mathrm{~s}^{-1} ; \mathrm{n}=6\right.$ species). Averaged $\mathrm{ETR}_{\max }$ values of seaweeds from midlittoral (9 species) and infralittoral (12 species) were similar and close to $24 \mu \mathrm{mol} \mathrm{e}^{-} \mathrm{m}^{-2} \mathrm{~s}^{-1}$. The example curves in Fig. 3 also indicated that some species from the infralittoral zone (e.g. Durvillaea antarctica) and subtidal locations (e.g. Lessonia trabeculata) can exhibit high rates of photosynthesis (up to $40 \mu \mathrm{mol} \mathrm{e}^{-}$ $\mathrm{m}^{-2} \mathrm{~s}^{-1}$ ), comparable to the rates of algae inhabiting ocations higher up the shore.

When the photosynthetic parameters $E_{\mathrm{k}}$ and $\alpha$ were organized according to the vertical distribution, morpho-functional and major taxonomic classification of seaweeds, some patterns could be identified (Fig. 4). In general, photosynthesis was found to be saturated at lower irradiance levels than the highest irradiances present at their natural depths. Thus, the light demand for the saturation of $\mathrm{ETR}_{\max }$ was in the range of irradiances reaching depths $>9 \mathrm{~m}$ below EHWS (see Fig. 1). Algae from the supralittoral zone had $E_{\mathrm{k}}$ values close to $230 \mu \mathrm{mol} \mathrm{m} \mathrm{m}^{-2} \mathrm{~s}^{-1}$, decreasing towards the midlittoral fringe (mean values $<140 \mu \mathrm{mol} \mathrm{m} \mathrm{m}^{-2} \mathrm{~s}^{-1}$; $\mathrm{p}<0.05$, Tukey HSD). In the sublittoral zone, the average $E_{\mathrm{k}}$ was close to $55 \mu \mathrm{mol} \mathrm{m}{ }^{-2} \mathrm{~s}^{-1}$ ( $<<0.005$, Tukey HSD). In the case of morpho-functional groups, delicate morphs such as filamentous and sheet-like species had $E_{\mathrm{k}}$ values close to 136 and $201 \mu \mathrm{mol} \mathrm{m} \mathrm{m}^{-2}$ $\mathrm{s}^{-1}$, respectively, higher than coarsely branched algae $\left(81 \mu \mathrm{mol} \mathrm{m} \mathrm{m}^{-2} \mathrm{~s}^{-1}\right.$; $\mathrm{p}<$ 0.005, Tukey HSD; Fig. 4B). However, thicker algae with leathery gross morphology (mainly kelps) exhibited high light requirements for photosynthesis $\left(122 \mu \mathrm{mol} \mathrm{m} \mathrm{m}^{-2} \mathrm{~s}^{-1}\right)$ comparable to filamentous species ( $\mathrm{p}>0.005$, Tukey HSD). In terms of taxonomic division (defined in this study as a thallus complexity gradient), $E_{\mathrm{k}}$ values varied less, with green algae in general exhibiting 

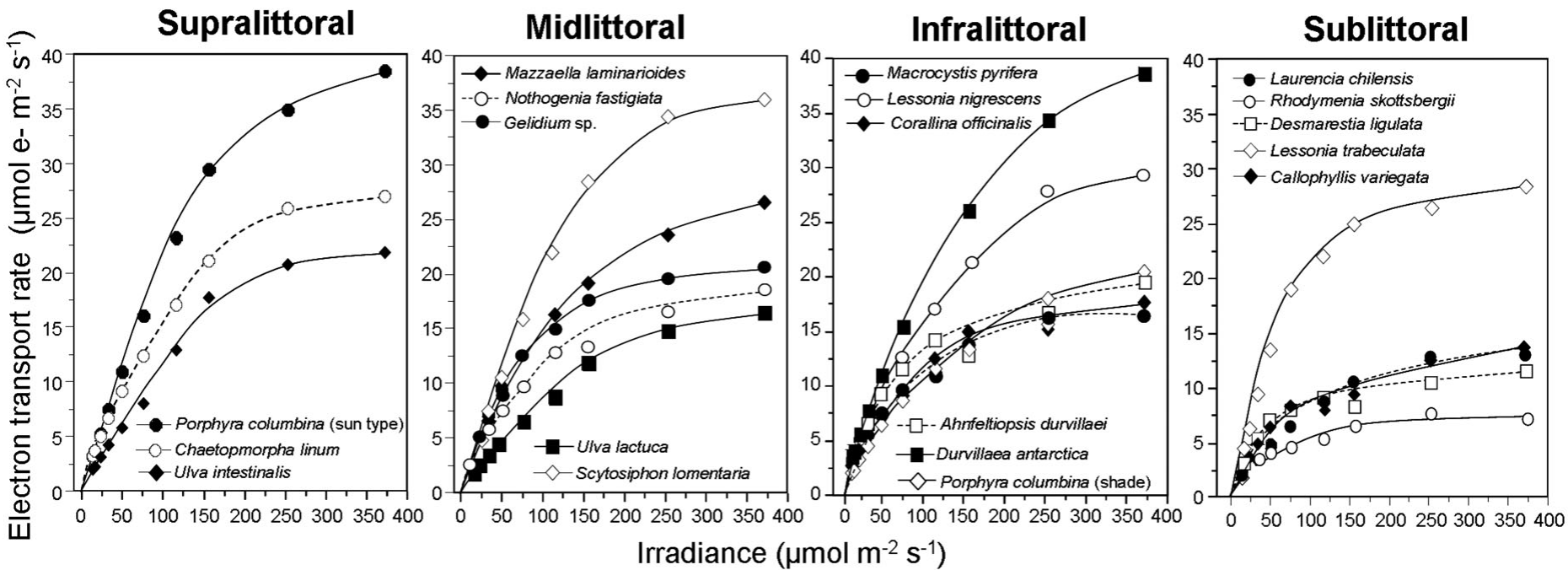

Fig. 3. Photosynthesis versus light curves using pulse amplitude modulation (PAM) fluorescence for some of the studied species from different depth zones. Light intensities were provided by the halogen lamp of the PAM-2000 fluorometer. Data are means of 3 to 6 measurements. Standard errors were $<5 \%$ and are not shown for clarity. These data are complementary to $E_{\mathrm{k}}$ and $\alpha$ values summarized in Fig. 4
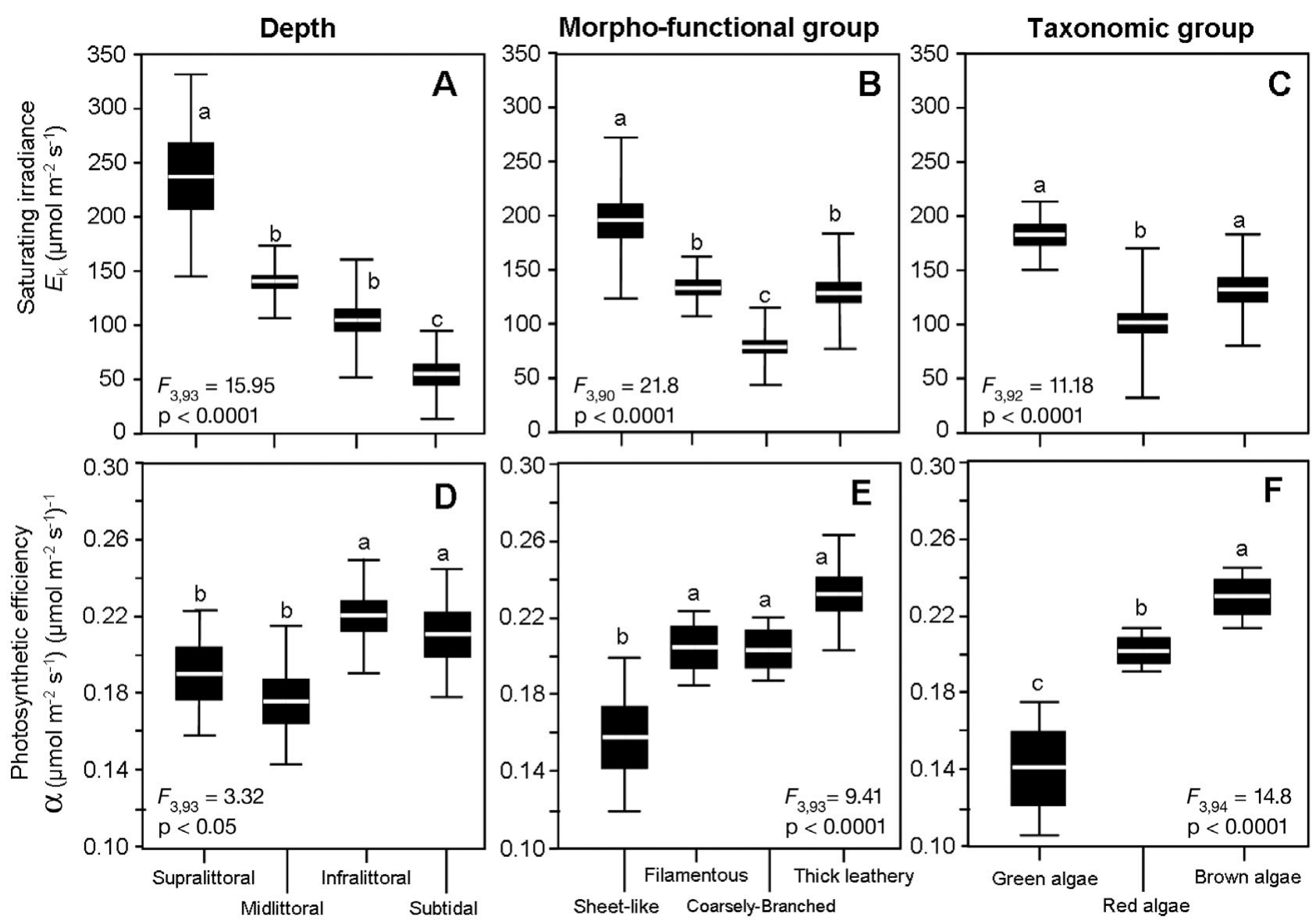

Fig. 4. Saturating irradiance point for photosynthesis $\left(E_{k}\right)$ and the initial slope $(\alpha)$ of several seaweed species according to $(A, D)$ depth zones, $(B, E)$ morpho-functional groups, and $(C, F)$ major taxonomic grouping. Data represent mean (white line) \pm SE (box limits) and \pm SD (whiskers) of different species within each group. Similar letters connect homogeneous mean groups (ANOVA, 
higher values $\left(105 \mu \mathrm{mol} \mathrm{m} \mathrm{m}^{-2} \mathrm{~s}^{-1}\right)$ than brown and red algae ( $\mathrm{p}<0.005$, Tukey HSD; Fig. 4C).

The initial slope of P-I curves $(\alpha)$, which is an indicator of photosynthetic efficiency, exhibited differences associated with depth variation, morpho-functional, and taxonomic groups. The $\alpha$ values measured in seaweeds from the supra- and midlittoral zone were significantly lower than those obtained in infra- and sublittoral locations (Fig. 4D). Sheet-like morphs exhibited the lowest $\alpha$ values (means close to $0.16 \mu \mathrm{mol} \mathrm{e}^{-} \mathrm{m}^{-2} \mathrm{~s}^{-1}$ $\left(\mu \mathrm{mol} \mathrm{m} \mathrm{m}^{-2} \mathrm{~s}^{-1}\right)^{-1} ; \mathrm{p}>0.05$, Tukey HSD), whereas filamentous, coarsely-branched and thick leathery morphs had similar values $(\mathrm{p}>0.05$, Tukey HSD, Fig. 4E). The brown algae clearly presented the highest and the green algae the lowest $\alpha$ values ( $p<0.05$; Tukey HSD, Fig. 4F).

The degree of photoinhibition of photosynthesis was not correlated with the light requirements of photosynthesis in the selected species from the 4 tidal zones; however, a tendency for a more rapid recovery from light stress in the upper littoral algae compared to infra- and sublittoral species was observed (Table 3). Over a light range of 1500 (low tide) to $550 \mu \mathrm{mol} \mathrm{m}{ }^{-2} \mathrm{~s}^{-1}$ (high tide), the decrease of $F_{\mathrm{v}} / F_{\mathrm{m}}$ at noon for intertidal species ranged between 34 and $74 \%$, irrespective of the depth of collection or functional-form grouping. In the shallow sublittoral red algae Laingia hookeri and
Gracilaria chilensis, which were exposed to PAR irradiances between 550 and $1000 \mu \mathrm{mol} \mathrm{m} \mathrm{m}^{-2} \mathrm{~s}^{-1}$, photoinhibition was 71 and $19 \%$ (the lowest value recorded for all studied species), respectively. In general, the time required for full recovery in the afternoon varied between 2.5 and $6 \mathrm{~h}$ for supra- and midlittoral species, whereas algae from infra- and sublittoral locations required between 5 and $8 \mathrm{~h}$ for complete recovery. In L. hookeri, recovery took longer (overnight; Table 3).

The bio-optical parameters of algae (total chlorophyll content, thallus absorptance, thickness, and area/weight quotient) exhibited some patterns related to their depth zonation, morpho-functional grouping, and algal division (Fig. 5). Supralittoral assemblages had the highest chlorophyll content and area/weight quotients, and the lowest absorptance and thickness $(p<0.05)$. These values were comparable to those measured in midlittoral algae $(p>0.05)$. In contrast, these parameters, with the exception of thickness, were similar in infra- and sublittoral species $(p>0.05$; Fig. 5A). Such depth patterns were related to the variation between different morpho-functional groups and their distribution across the shore (Fig. 5B). Filamentous and sheet-like morphs, which dominate the supralittoral zones, were characterized by higher pigmentation per weight unit and higher area/weight quotients $(\mathrm{p}<0.05)$, whereas in coarsely branched and

Table 3. Light-use characteristics of selected seaweed species from different positions on the shore and different morphofunctional groups. Saturation points of photosynthesis were calculated from fluorescence based P-I curves. Percentage photoinhibition and time for recovery was estimated from the daily course of $F_{\mathrm{v}} / F_{\mathrm{m}}$ under natural solar radiation (see 'Materials and methods' for details). The range of maximal irradiances to which algae can be exposed at their vertical distribution is also indicated. Data are means \pm SD ( $n=6-10$ measurements). Calculations of irradiances were made using an estimated value of $1500 \mu \mathrm{mol} \mathrm{m}^{-2} \mathrm{~s}^{-1}$ at $0 \mathrm{~m}$ at low tide, and the differences reaching the lower depth levels for each tidal zone were estimated using the vertical attenuation coefficient for downward irradiance, $K_{\mathrm{d}}$

\begin{tabular}{|c|c|c|c|c|c|}
\hline Littoral zone/species & $\begin{array}{l}\text { Depth range } \\
(\mathrm{m})\end{array}$ & $\begin{array}{l}\text { Maximum irradiance } \\
\text { Low tide-high tide } \\
\left(\mu \mathrm{mol} \mathrm{m} \mathrm{m}^{-2} \mathrm{~s}^{-1}\right)\end{array}$ & $\begin{array}{c}E_{\mathrm{k}} \\
(\%)\end{array}$ & $\begin{array}{l}\text { Photoinhibition of } \\
\text { photosynthesis } \\
\text { (h) }\end{array}$ & $\begin{array}{l}\text { Time to full } \\
\text { recovery }\end{array}$ \\
\hline \multicolumn{6}{|l|}{ Supralittoral fringe } \\
\hline Porphyra columbina (sun type) & $0-0.2$ & $1500-1400$ & $333 \pm 7.6$ & $64 \pm 6.5$ & 4 \\
\hline Ulva intestinalis & $0-0.5$ & $1500-1350$ & $196 \pm 54.2$ & $33 \pm 9.3$ & 2.5 \\
\hline Chaetomorpha linum & $0-0.5$ & $1500-1350$ & $178 \pm 17.9$ & $39 \pm 11.7$ & 2.5 \\
\hline \multicolumn{6}{|l|}{ Midlittoral zone } \\
\hline Gelidium lingulatum & $0.5-1.5$ & $1500-1100$ & $113 \pm 11.1$ & $35 \pm 11.7$ & 6 \\
\hline Mazzaella laminarioides & $0.5-1.5$ & $1500-1100$ & $136 \pm 21.1$ & $47 \pm 13.9$ & 3 \\
\hline Ulva rigida & $0.5-1.5$ & $1500-1100$ & $171 \pm 11.0$ & $49 \pm 13.4$ & 2.5 \\
\hline \multicolumn{6}{|l|}{ Infralittoral fringe } \\
\hline Durvillaea antarctica & $1.5-2.0$ & $1500-1000$ & $237 \pm 32.5$ & $49 \pm 4.3$ & 7 \\
\hline Grateloupia doryphora & $1.5-2.0$ & $1500-1000$ & $82 \pm 20.1$ & $73 \pm 6.5$ & 5 \\
\hline Lessonia nigrescens & $1.5-2.0$ & $1500-1000$ & $148 \pm 51.4$ & $50 \pm 14.8$ & 8 \\
\hline Porphyra columbina (shade type) & $1.5-2.0$ & $1500-1000$ & $154 \pm 10.2$ & $58 \pm 15.5$ & 6 \\
\hline \multicolumn{6}{|l|}{ Sublittoral zone } \\
\hline Laingia hookeri & $3.0-5.0$ & $1000-550$ & $101 \pm 6.9$ & $70 \pm 14.4$ & $>12$ \\
\hline Gracilaria chilensis & $3.0-5.0$ & $1000-550$ & $99 \pm 28.4$ & $19 \pm 3.6$ & 5 \\
\hline
\end{tabular}



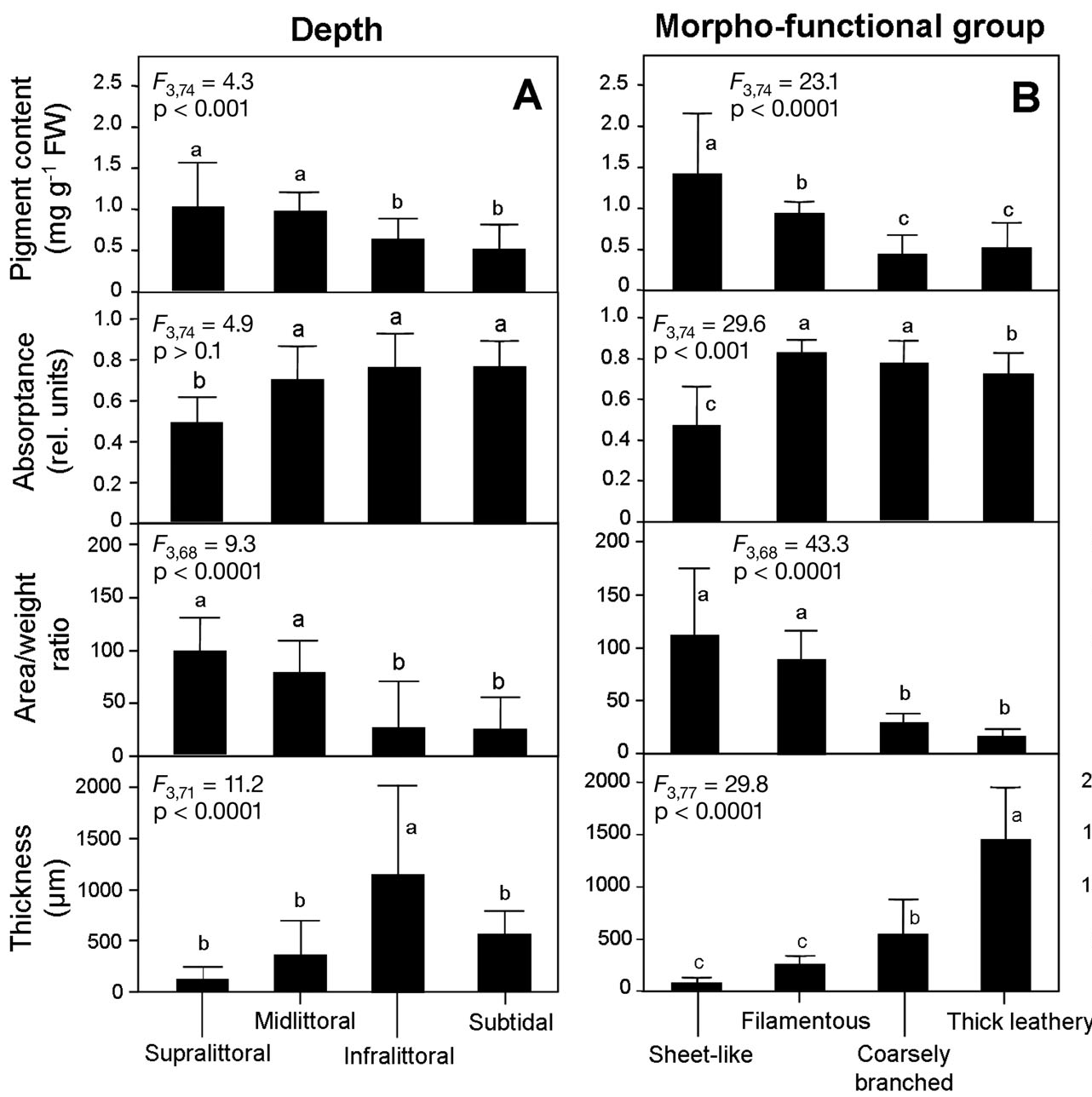

Taxonomic group

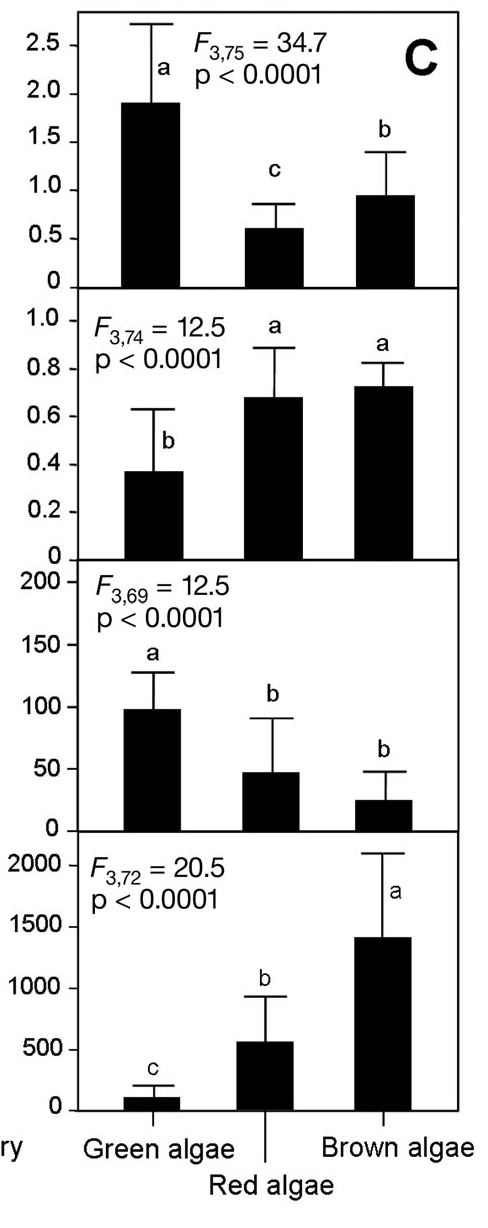

Fig. 5. Chlorophyll content, light absorptance, area/weight quotient, and thallus thickness according to (A) depth zones, (B) morpho-functional groups, and (C) major algal divisions. Data represent mean \pm SD of different species within each group as defined in the 'Materials and methods' section. Similar letters connect homogeneous mean groups (ANOVA, Tukey HSD post hoc test)

thick leathery forms (most common in mid- and infralittoral sites), the pattern was reversed (Fig. 5B). Green algae exhibited the highest pigmentation and area/weight quotient, while average thickness was highest in brown algae $(p<0.05)$. Absorptance in general was lower in green compared to red and brown algae (Fig. 5C).

\section{Thallus absorptance and morpho-functional relationships}

A relationship between thallus absorptance and thickness was found (Fig. 6). Delicate morphs, e.g. Porphyra and Ulva, are characterized by thalli as thin as $<100 \mu \mathrm{m}$. In Ulva species, the spectral light absorptance was reduced by approximately $30 \%$ at wave- lengths of 500 to $650 \mathrm{~nm}$ as a consequence of a low absorption of chlorophylls at these wavelengths, while in the rhodophyte Porphyra columbina, the absorptance was considerably enhanced at these wavelengths. In algae with thicknesses between 0.3 and $1 \mathrm{~mm}$, represented mainly by coarsely branched morphs such as Laurencia, Nothogenia, and Gelidium, the light absorptance in this spectral range was around $80 \%$ of the maximum absorptance. In thick leathery morphs such as Durvillaea, lamina can be as thick as 2 to $3 \mathrm{~cm}(\mathrm{p}<0.05)$, and thus the absorptance reaches $>90 \%$ across the wavelength range between 300 and $700 \mathrm{~nm}$. The higher absorptance of coarsely branched and leathery forms at these wavelengths was not only due to the thickness but probably also to a higher concentration of accessory pigments increasing spectral absorption. 
Thallus thickness $(\mathrm{mm})$
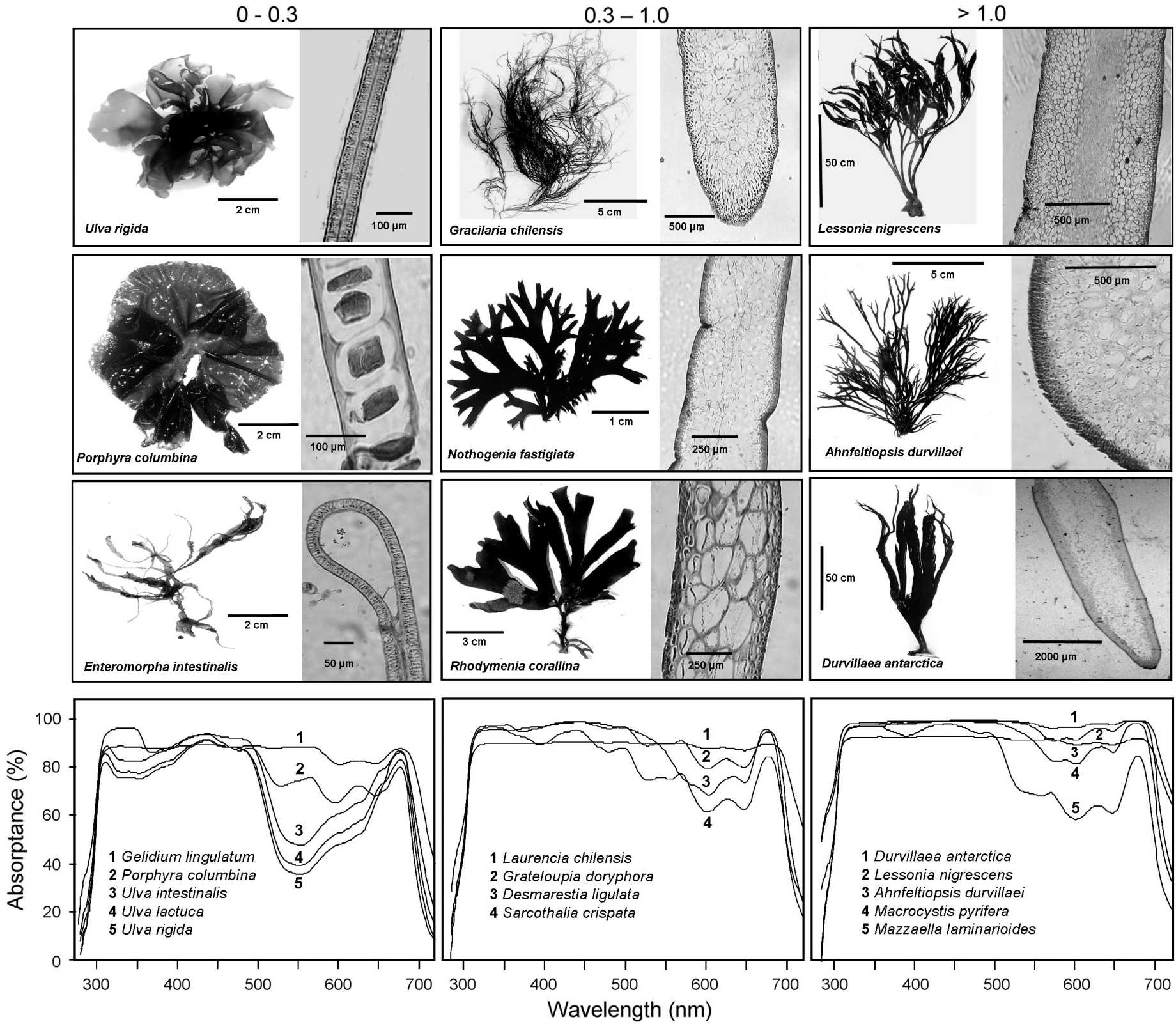

Fig. 6. In vivo absorptance spectra of selected macroalgae and their relationship to thallus thickness (mean \pm SD). Three examples of thallus cross-sections are shown for each group

\section{DISCUSSION}

\section{Light availability versus photosynthetic requirements}

Based on the $E_{\mathrm{k}}$ values of 32 species that varied between 20 and $320 \mu \mathrm{mol} \mathrm{m}{ }^{-2} \mathrm{~s}^{-1}$, seaweeds from upper littoral zones exhibited higher light demands and a lower photosynthetic efficiency $(\alpha)$ than algae growing in infralittoral and shallow sublittoral locations. Taking into account the relationship found between $E_{\mathrm{k}}$ values of algae and the light availability measured in summer under optimal conditions (Fig. 1 and Table 3), the light needed to saturate photosynthesis occurred down to a depth of around $9 \mathrm{~m}$. These light demands are much lower than the underwater irradiances over a depth gradient from supra- to sublittoral zones, and thus it could be argued that these algae are metabolically able to photosynthesize across a broad range of light conditions. For example, if one assumes seasonal $E_{\mathrm{k}}$ acclimation and taking into account that during winter, light can be $40 \%$ of the values recorded in summer 
(Huovinen et al. 2006), photosynthesis is well supported in the upper $5 \mathrm{~m}$ of the water column (below ELWS) in any season. This pattern resembles that reported for seaweed assemblages in the northern hemisphere (Johansson \& Snoeijs 2002, Middelboe \& Binzer 2004) and some polar communities (Gómez et al. 2009). In Arctic and Antarctic seaweeds, as a response to extreme seasonal variability in light availability, $E_{\mathrm{k}}$ values can be as low as $10 \mu \mathrm{mol} \mathrm{m} \mathrm{m}^{-2} \mathrm{~s}^{-1}$, allowing some species with wide vertical distributions to reach depths close to 30 to $40 \mathrm{~m}$ (Dunton \& Jodwalis 1988, Gómez et al. 1997, Dunton et al. 2009). Minimum light requirements estimated using light penetration and SeaWiFS data for different functional groups of seaweeds and seagrasses worldwide range between 23 and $0.3 \mu \mathrm{mol}$ $\mathrm{m}^{-2} \mathrm{~s}^{-1}$ (Gattuso et al. 2006). Moreover, recent surveys from tropical assemblages with light levels as low as $0.01 \%$ of the surface irradiance present in their habitat confirm that many seaweeds, by virtue of their extremely low light requirements for photosynthesis, can photosynthesize at considerable depths (Runcie et al. 2008).

Tidal oscillation has considerable influence on light availability in the context of seaweed zonation (Dring \& Lüning 1994). For example, infralittoral zones from Patagonian fjords with a 6 to $7 \mathrm{~m}$ tidal range are exposed to $40 \%$ less PAR during low tide than during high tide. On the coast around Valdivia, due to a small tidal range $(2 \mathrm{~m})$, incident light on infralittoral substrates is reduced by $15 \%$ during high tide (Huovinen \& Gómez 2010). On the other hand, the height of the water column not only affects the photon fluence rates reaching the algae but also the spectral composition of the light. During a tidal cycle, the spectral distribution of light across the entire littoral range can oscillate from the whole solar spectrum to light qualities where some biologically relevant PAR wavelengths are strongly attenuated (Jerlov 1976, Lüning 1990, Kirk 1994).

\section{Zonation and light stress tolerance of seaweeds}

The poor correlation of light requirements for photosynthesis with the light availability in the littoral zone found in this study points to adaptations that have evolved to cope with excess solar radiation. The results of photoinhibition of photosynthesis, a downregulation mechanism to quench excess solar energy (reviewed by Demmig-Adams et al. 2008), indicates that algae from different depths exhibited similar rates of photoinhibition, but the time for recovery was comparatively shorter in upper littoral species compared to seaweeds from infra- or sublittoral zones (Table 3). Interestingly, such responses were not asso- ciated with morpho-functional grouping, confirming previous results for intertidal algae (Gómez et al. 2004). A rapid recovery of photosynthesis in species from shallower depths would be a general response explained by an increased time-use efficiency of algae exposed for longer periods to enhanced environmental stress (e.g. high solar radiation, desiccation, and temperature; Dring \& Brown 1982, Dudgeon et al. 1995, Skene 2004).

During low tide, seaweeds are exposed to higher levels of UV radiation. The spectral attenuation of solar UV radiation at the present study site was close to 1.8 and $0.80 \mathrm{~m}^{-1}$, equivalent to penetration depths (1\%) of 2.5 and $5.8 \mathrm{~m}$ for UV-B and UV-A, respectively. Although these values were in the range reported for coastal waters (reviewed by Tedetti \& Sempéré 2006), the enhancement of UV-B radiation due to the stratospheric ozone depletion in southern latitudes (Lovengreen et al. 2000, Frederick et al. 2001) may increase its impact on seaweeds (Bischof et al. 1998, Rautenberger et al. 2009, Huovinen \& Gómez 2011). In southern Chile, current levels of UV radiation can be detrimental to photosynthesis and cause DNA damage, especially in seaweeds from the lower intertidal zones (Huovinen et al. 2006). For example, around 40\% photoinhibition has been measured in the infralittoral kelp Lessonia nigrescens, while algae from the supra-/ midlittoral zone exhibit $<10 \%$ photoinhibition (Huovinen et al. 2006, Gómez et al. 2007).

It must be emphasized that the effect of UV varies between species (Wahl et al. 2004, Bancroft et al. 2007), and additionally, seaweeds are able to counteract the negative UV effects through different adaptive responses (reviewed by Bischof et al. 2006b, Karsten et al. 2009). Based on pure optics only, one may argue that thicker seaweeds by virtue of their characteristics (e.g. self-shading, multiple cell layers) could be better protected from negative UV effects than delicate forms. However, our results and some previous studies (Gómez et al. 2004, Huovinen et al. 2006) indicate that filamentous and sheet-like forms (common at upper sites) compensate for the negative effects of high UV exposure by efficient photochemical adjustments such as dynamic photoinhibition. On the other hand, UV-B strongly affects the early stages of seaweeds, which has been promoted as a factor in determining the zonation pattern (Roleda et al. 2005, Wiencke et al. 2006). The susceptibility of small gametophytes of some red algae to DNA damage has been found to be directly related to their position on the shore (Roleda et al. 2004). However, although a potential effect on seaweed assemblages at depths close to the surface is expected (Fig. 7), the question of whether this affects the seaweed zonation structure and the dynamics of the studied coastal systems requires further research. 


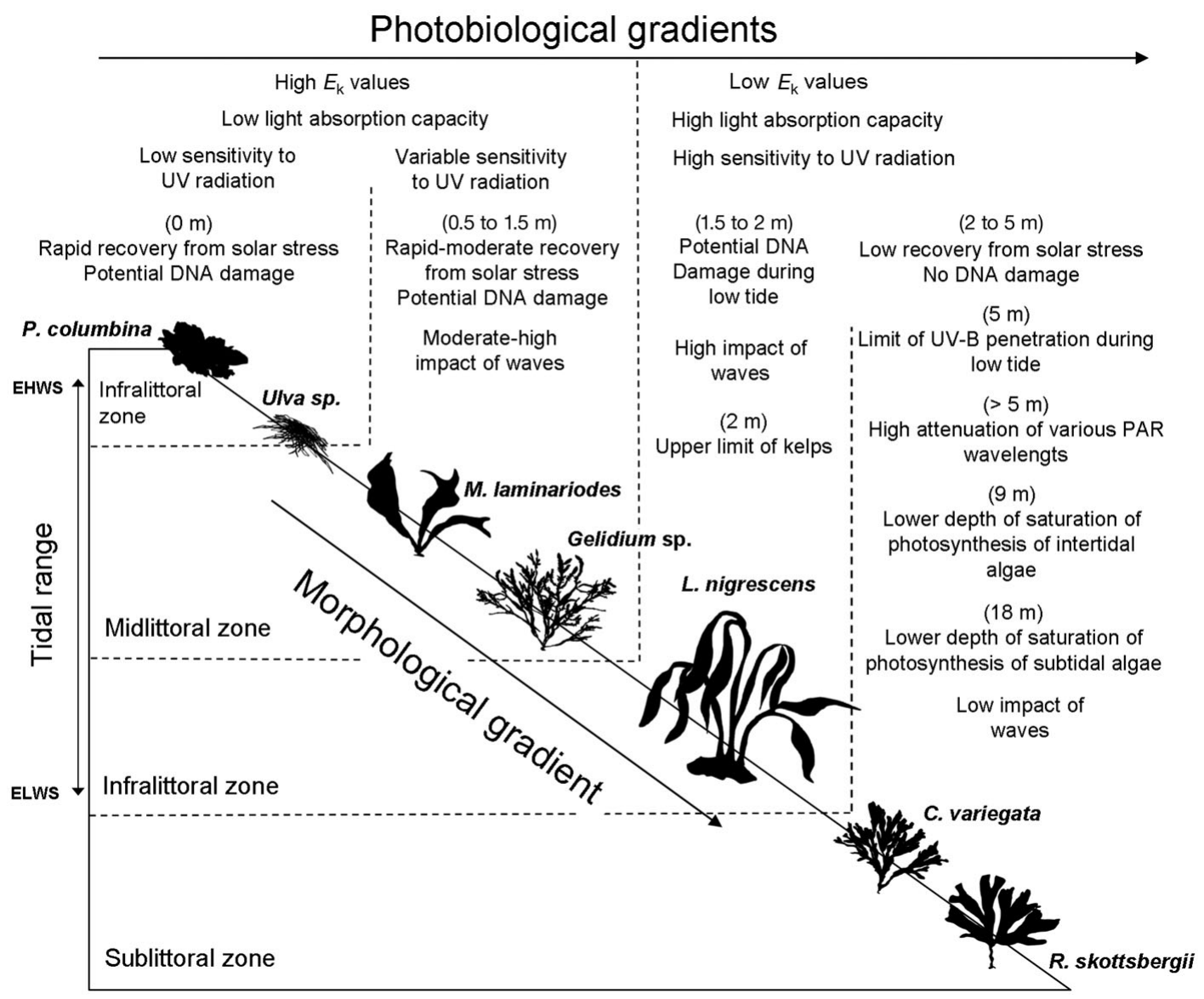

Fig. 7. Seaweed zonation on the southern Pacific coast of southern Chile and a synopsis of the main photobiological, morphological, and environmental gradients. The dominant seaweed species in each littoral zone are indicated. $E_{\mathrm{k}}$ : saturating irradiance point for photosynthesis; EHWS: extreme high water spring tide; ELWS: extreme low water spring tide; PAR: photosynthetically active radiation

\section{Do morphological traits delineate photobiological adaptations?}

The light-absorption capacity of benthic algae depends on thallus thickness and less on phylogeny (Enriquez et al. 1994, Smith \& Alberte 1994, Grzymski et al. 1997). In this study, the discriminant analysis indicated that bio-optical and photosynthetic properties of algae contributed significantly to the variability between different morpho-functional groups. Although we did not consider the suite of accessory pigments, which is essentially different in each of the distinct algal groups, the absorptances measured in 32 algal species were higher in brown and red algae than in green algae. On the other hand, algae with thicker morphs (thick-leathery and coarsely branched) had the highest absorptance but the lowest chlorophyll content per weight unit (Fig. 5). In general, the composition of the light-harvesting systems could be relevant when the energy cost involved in pigment synthesis is considered. For example, energy costs for synthesis of phycobilins are relatively higher than required for synthesis of other chromophores (Raven 1984). Overall, the spectral absorptance of the algae in our study reflected the pattern of depth distribution of the gross morphologies. At upper littoral locations, the prevalence of delicate morphs (green and some red algae), which are characterized by optically less dense structures, suggests that an effective light-harvesting setup (e.g. lower package effect) is not reflected in the depth gradient of the intertidal system. Instead, the lower light absorptances of these organisms suggest a low efficiency of photon capture as compared to thicker algae distributed deeper. In deeper habitats, adaptations to water movement lead to the dominance of optically dense algae at infralittoral locations; however, thick algae could provide optical advantages by virtue of their ability to use an impoverished range of wavelengths that excite chlorophylls more efficiently, as has been demonstrated through action spectra for photosynthesis (Lüning \& Dring 1985). Functionally, thallus absorptance in thicker, optically 'black' algae is 
independent of their pigment content, which minimizes the package effect in a light field subject to changing spectral composition (Henley \& Ramus 1989, Raven \& Kübler 2002). By contrast, in thin morphs from shallower locations, subject to high prevailing irradiances, metabolic strategies that developed to cope with excess light energy (e.g. dynamic photoinhibition) are more important for primary production than investments in light-absorbing capacities (Lüning 1990, Henley 1993).

\section{Thallus form hypothesis}

The form-function hypothesis of Littler \& Littler (1980) suggests that similar morphs exhibit comparable physiological traits or respond similarly to environmental factors, whereas algae with different morphology are ecophysiologically heterogeneous. However, in the context of the zonation described in the present study, the morpho-functional adaptations predicted by the Littler model may only be partially related to light gradients. As was previously indicated, although in general the suite of photosynthetic and bio-optical variables used in the present study discriminated well between the different groups of algae, some traits exhibited different tendencies. For example, in the upper littoral zones, thallus absorptance and thickness of algae were low, suggesting a lower light-absorption capacity than in species from other littoral locations; however, photosynthetic parameters (e.g. ETR max $_{\text {and }}$ $E_{\mathrm{k}}$ ) and chlorophyll content per weight unit were higher compared to algae inhabiting lower littoral zones. In the infralittoral and upper sublittoral, algae are generally large and complex, exhibiting higher light-harvesting capacities, but photosynthesis was lower. It must be emphasized that the inherent biooptical and photosynthetic properties in each morphofunctional group in the context of the zonation was strongly indicated by the taxonomic category, i.e. green algae were represented mainly by foliose and filamentous morphs, red algae by coarsely-branched forms and brown algae by thick leathery forms. However, there are some exceptions, e.g. the articulate Corallina officinalis and the prostrate green alga Codium dimorphum that do not fit this general morphological pattern.

Our study confirms that gross morphology is not associated with the UV stress tolerance or the capacity for photoinhibition (Gómez et al. 2004). Rather, the position on the shore, irrespective of morpho-functional and taxonomic grouping, was determined as the most important factor, which is in accordance with studies from other biogeographical regions (Larkum \& Wood 1993, Aguilera et al. 1999). When subtidal algae (which are not exposed to high solar radiation) are included, other photobiological capacities, such as low light requirements for photosynthesis, enhanced lightabsorption capacity, and positive metabolic carbon balance, are paramount and set the metabolic depth limits for growth (Markager \& Sand-Jensen 1992, Gómez et al. 1997, Binzer \& Sand-Jensen 2002). Clearly, some of the morpho-functional adaptations of algae have developed to cope with variable light availability and can confer advantages when coping with other environmental factors such as desiccation and temperature (Dudgeon et al. 1995).

In large brown algae inhabiting the infralittoral zone (e.g. Lessonia and Durvillaea), a substantial proportion of the biomass is allocated to the holdfasts and stipes as a means of withstanding high wave impact and drag stresses (Westermeier \& Gómez 1996). This has important implications for photobiology: the basal zones of the thallus are carbon sink regions and are more resistant to solar stress (including UV radiation) than fronds, which are transient structures exhibiting a low tolerance to solar stress (Gómez et al. 2007). In the supra- and midlittoral zones, the morphological adaptations of algae (e.g. Chaetomorpha and Ulva) may include the formation of mats, where the upper layers endure the direct impact of solar stress and desiccation, while subcanopy individuals remain unaffected (Bischof et al. 2002, 2006b).

Overall, some general tendencies in the light-use characteristics, gross morphology, and environmental gradients can be outlined (Fig. 7). In the context of zonation, (1) light adaptations of seaweeds that permit algae to tolerate high light stress, including enhanced solar UV radiation (e.g. rapid recovery from photoinhibition), operate similarly across different morphofunctional and taxonomic groups, i.e. these traits are not correlated with classical form-function schemes; (2) In contrast, bio-optical traits associated with lightabsorption characteristics (e.g. absorptance, pigmentation, and thickness), are strongly linked to morphological categories according to the Littler formfunction model and are distributed across a depth gradient. For example, filamentous and sheet-like seaweeds with lower absorptance, thickness, and area/ weight quotient dominate in the upper intertidal zones, where light is clearly not limiting. However, algae with massive and complex thalli (e.g. kelps), exhibit higher enhanced capacities for light absorption, which are completely, or in great part, defined by morphological traits that confer advantages in coping with the higher water dynamics of the infralittoral zone; (3) Photosynthetic parameters also exhibit a relationship between gross morphology and depth, i.e. delicate morphologies (e.g. filamentous and foliose forms) that dominate the upper littoral zone in general exhibit 
higher $E_{\mathrm{k}}$ and lower $\alpha$ values than thicker seaweeds from lower littoral zones. However, light requirements for photosynthesis recorded for the studied seaweeds were clearly not set by the underwater solar radiation. The low light requirements for photosynthesis (averages 50 to $320 \mu \mathrm{mol} \mathrm{m} \mathrm{m}^{-2} \mathrm{~s}^{-1}$ ), a pre-condition for acclimation to low light conditions, and the high absorption capacity of mid- and infralittoral algae may represent a physiological potential for expanding their distribution downwards; however, their occurrence at deeper depths is constrained by other physical and biological factors.

Acknowledgements. Funding provided by the Fondecyt Grant (No 1060503) and the Project Bicentenario de Ciencia y Tecnología (IPA09, Conicyt and World Bank) is acknowledged. We thank M. Orostegui for the excellent technical assistance in analyses of algae and M. Lee for checking the language.

\section{LITERATURE CITED}

Ackerly DD, Reich PB (1999) Convergence and correlations among leaf size and function in seed plants: a comparative test using independent contrasts. Am J Bot 86:1272-1281

Aguilera J, Karsten U, Lippert H, Vögele B, Philipp E, Hanelt D, Wiencke C (1999) Effects of solar radiation on growth, photosynthesis and respiration of marine macroalgae from the Arctic. Mar Ecol Prog Ser 191:109-119

Bancroft BA, Baker NJ, Blaustein AR (2007) Effects of UV-B radiation on marine and freshwater organisms: a synthesis through meta-analysis. Ecol Lett 10:332-345

Benedetti-Cecchi L, Bulleri F, Cinelli F (2000) The interplay of physical and biological factors in maintaining midshore and low-shore assemblages on rocky coasts in the northwest Mediterranean. Oecologia 123:406-417

Binzer T, Sand-Jensen K (2002) Production in aquatic macrophyte communities: a theoretical and empirical study of the influence of spatial light distribution. Limnol Oceanogr 47:1742-1750

Bischof K, Hanelt D, Wiencke C (1998) UV-radiation can affect depth-zonation of Antarctic macroalgae. Mar Biol 131:597-605

Bischof K, Peralta G, Kräbs G, van de Poll WH, Pérez-Lloréns JL, Breeman A (2002) Effects of solar UV-B radiation on canopy structure of Ulva communities from southern Spain. J Exp Bot 53:2411-2421

Bischof K, Rautemberger R, Brey L, Pérez-Lloréns JL (2006a) Physiological acclimation to gradients of solar irradiance within mats of the filamentous green macroalga Chaetomorpha linum from southern Spain. Mar Ecol Prog Ser 306:165-175

Bischof K, Gómez I, Molis M, Hanelt D and others (2006b) Ultraviolet radiation shapes seaweed communities. Rev Environ Sci Biotechnol 5:141-166

Chapman VJ, Chapman DJ (1976) Life forms in algae. Bot Mar 19:65-74

Demmig-Adams B, Adams WW III, Mattoo AK (2008) Photoprotection, photoinhibition, gene regulation, and environment. Springer, Dordrecht

> Dring MJ (1981) Chromatic adaptation of photosynthesis in benthic marine algae: an examination of its ecological significance using a theoretical model. Limnol Oceanogr 26: $271-284$
Dring MJ, Brown FA (1982) Photosynthesis of intertidal brown algae during and after periods of emersion: a renewed search for physiological causes of zonation. Mar Ecol Prog Ser 8:301-308

> Dring MJ, Lüning K (1994) Influence of spring-neap tidal cycles on the light available for photosynthesis by benthic marine plants. Mar Ecol Prog Ser 104:131-137

Dring MJ, Wagner A, Boeskow J, Lüning K (1996) Sensitivity of intertidal and subtidal red algae to UVA and UVB radiation, as monitored by chlorophyll fluorescence measurements: influence of collection depth and season, and length of irradiation. Eur J Phycol 31:293-302

Dudgeon SR, Kübler JE, Vadas RL, Davison IR (1995) Physiological responses to environmental variation in intertidal red algae: does thallus morphology matter? Mar Ecol Prog Ser 117:193-206

Dunton KH, Jodwalis CM (1988) Photosynthetic performance of Laminaria solidungula measured in situ in the Alaskan High Arctic. Mar Biol 98:277-285

Dunton KH, Schonberg SV, Funk DW (2009) Interannual and spatial variability in light attenuation: evidence from three decades of growth in the arctic kelp, Laminaria solidungula. Proceedings of Smithsonian at the Poles Symposium, Smithsonian Institution, Washington, DC, 3-4 May 2007. Smithsonian Institute Scholarly Press, Washington, DC

Enriquez S, Agusti S, Duarte CM (1994) Light absorption by marine macrophytes. Oecologia 98:121-129

Franklin LA, Forster RM (1997) The changing irradiance environment: consequences for marine macrophyte physiology, productivity and ecology. Eur J Phycol 32:207-232

Frederick JE, Manner VW, Booth CR (2001) Interannual variability in solar ultraviolet irradiance over decadal time scales at latitude $55^{\circ}$ south. Photochem Photobiol 74 : $771-779$

Gattuso JP, Gentili B, Duarte CM, Kleypas JA, Middelburg JJ, Antoine D (2006) Light availability in the coastal ocean: impact on the distribution of benthic photosynthetic organisms and contribution to primary production. Biogeosci Discuss 3:895-959

Gómez I, Weykam G, Klöser H, Wiencke C (1997) Photosynthetic light requirements, metabolic carbon balance and zonation of sublittoral macroalgae from King George Island (Antarctica). Mar Ecol Prog Ser 148:281-293

Gómez I, Figueroa FL, Ulloa N, Morales V, Lovengreen C, Huovinen P, Hess S (2004) Patterns of photosynthesis in 18 species of intertidal macroalgae from southern Chile. Mar Ecol Prog Ser 270:103-116

Gómez I, Orostegui M, Huovinen P (2007) Morpho-functional patterns of photosynthesis in the south Pacific kelp Lessonia nigrescens: effects of UV radiation on ${ }^{14} \mathrm{C}$ fixation and primary photochemical reactions. J Phycol 43:55-64

Gómez I, Wulff A, Roleda MY, Huovinen P, Karsten U, Quartino ML, Dunton K, Wiencke C (2009) Light and temperature demands of marine benthic micro-algae and seaweeds in the polar regions. Bot Mar 52:593-608

Grime JP (1981) Plant strategies and vegetation processes. John Wiley \& Sons, New York, NY

Grzymski J, Johnsen G, Sakshaug E (1997) The significance of intracellular self-shading on the bio-optical properties of brown, red and green macroalgae. J Phycol 33:408-414

Hemminga MA, Duarte CM (2000) Seagrass ecology. Cambridge University Press, Cambridge

> Henley WJ (1993) Measurement and interpretation of photosynthetic light-response curves in algae in the context of photoinhibition and diel changes. J Phycol 29:729-739

> Henley WJ, Ramus J (1989) Optimization of pigment content and the limits of photo-acclimation for Ulva rotundata 
(Chlorophyta). Mar Biol 103:267-274

Huovinen P, Gómez I (2011) Spectral attenuation of solar radiation in Patagonian fjords and coastal waters and implications for algal photobiology. Cont Shelf Res 31 (in press)

> Huovinen P, Gómez I, Lovengreen C (2006) A five-year study of solar ultraviolet radiation in southern Chile $\left(39^{\circ} \mathrm{S}\right)$ : potential impact on coastal marine algae? Photochem Photobiol 82:515-522

Huovinen P, Gómez I, Oróstegui M (2007) Patterns and UV sensitivity of carbon anhydrase and nitrate reductase activities in south Pacific macroalgae. Mar Biol 151:1813-1821

Ingólfsson A (2005) Community structure and zonation patterns of rocky shores at high latitudes: an interocean comparison. J Biogeogr 32:169-182

Inskeep WP, Bloom PR (1985) Extinction coefficients of chlorophyll $a$ and $b$ in N,N-dimethylformamide and $80 \%$ acetone. Plant Physiol 77:483-485

Jassby AD, Platt T (1976) Mathematical formulation of the relationship between photosynthesis and light for phytoplankton. Limnol Oceanogr 21:540-547

Jerlov NG (1976) Marine optics. Elsevier, Amsterdam

> Johansson G, Snoeijs P (2002) Macroalgal photosynthetic responses to light in relation to thallus morphology and depth zonation. Mar Ecol Prog Ser 244:63-72

Karsten U, Wulff A, Roleda MY, Müller R, Steinhoff FS, Fredersdorf J, Wiencke C (2009) Physiological responses of polar benthic algae to ultraviolet radiation. Bot Mar 52:639-654

Kirk JTO (1994) Light and photosynthesis in aquatic ecosystems, $2^{\text {nd }}$ edn. Cambridge University Press, Cambridge

- Larkum AWD, Wood WF (1993) The effect of UV-B on photosynthesis and respiration of phytoplankton, benthic macroalgae and seagrasses. Photosynth Res 36:17-23

Larkum AWD, Orth RJ, Duarte CM (2006) Seagrasses: biology, ecology and conservation. Springer, Dordrecht

- Littler MM, Littler DS (1980) The evolution of thallus form and survival strategies in benthic marine macroalgae: field and laboratory tests of a functional form model. Am Nat 116:25-44

> Lovengreen C, Fuenzalida H, Villanueva L (2000) Ultraviolet solar radiation at Valdivia, Chile $\left(39.8^{\circ} \mathrm{S}\right)$. Atmos Environ 34:4051-4061

Lüning K (1990) Seaweeds: their environment, biogeography, and ecophysiology. Wiley-Liss, New York, NY

Lüning K, Dring MJ (1985) Action spectra and spectral quantum yield of photosynthesis in marine macroalgae with thin and thick thalli. Mar Biol 87:119-129

Markager S (1993) Light absorption and quantum yield for growth in five species of marine macroalgae. J Phycol 29: $54-63$

Markager S, Sand-Jensen K (1992) Light requirements and depth zonation of marine macroalgae. Mar Ecol Prog Ser 88:83-92

Middelboe AL, Binzer T (2004) Importance of canopy structure on photosynthesis in single- and multi-species assemblages of marine macroalgae. Oikos 107:422-432

Molina-Montenegro MA, Muñoz AA, Badano EI, Morales BW, Fuentes KM, Cavieres LA (2005) Positive associations between macroalgal species in a rocky intertidal zone and their effects on the physiological performance of Ulva lactuca. Mar Ecol Prog Ser 292:173-180

Orfanidis S, Panayotidis P, Stamatis N (2001) Ecological evaluation of transitional and coastal waters: a marine benthic macrophyte-based model. Mediterr Mar Sci 2:45-65

Padilla DK, Allen BJ (2000) Paradigm lost: reconsidering functional form and group hypothesis in marine ecology. J Exp Mar Biol Ecol 250:207-221

Editorial responsibility: Hans Heinrich Janssen, Oldendorf/Luhe, Germany
Poorter L, Bongers F (2006) Leaf traits are good predictors of plant performance across 53 rain forest species. Ecology 87:1733-1743

> Ramus J (1978) Seaweed anatomy and photosynthetic performance: the ecological significance of light guides, heterogeneous absorption and multiple scatter. J Phycol 14: $352-362$

Ramus J (1981) The capture and transduction of light energy. In: Lobban CS, Wynne MJ (eds) The biology of seaweeds. Blackwell, Oxford, p 458-492

> Rautenberger R, Mansilla A, Gómez I, Wiencke C, Bischof K (2009) Photosynthetic acclimation to UV-radiation of intertidal macroalgae from the Strait of Magellan (Chile). Rev Chil Hist Nat 82:43-61

Raven JA (1984) A cost-benefit analysis of photon absorption by photosynthetic unicells. New Phytol 98:593-625

Raven JA, Kübler JE (2002) New light on the scaling of metabolic rate with the size of algae. J Phycol 38:11-16

Roleda MY, van de Poll WH, Hanelt D, Wiencke C (2004) PAR and UVBR effects on photosynthesis, viability growth and DNA in different life stages of two coexisting Gigartinales: implications for recruitment and zonation pattern. Mar Ecol Prog Ser 281:37-50

Roleda MY, Wiencke C, Hanelt D, van de Poll WH, Gruber A (2005) Sensitivity of Laminariales zoospores from Helgoland (North Sea) to ultraviolet and photosynthetically active radiation: implications for depth distribution and seasonal reproduction. Plant Cell Environ 28:466-479

> Runcie JW, Gurgel CFD, Mcdermid KJ (2008) In situ photosynthetic rates of tropical marine macroalgae at their lower depth limit. Eur J Phycol 43:377-388

Santelices B (1989) Algas marinas de Chile. Ediciones Universidad Católica de Chile, Santiago

Schreiber U, Bilger W, Neubauer C (1994) Chlorophyll fluorescence as a non intrusive indicator for rapid assessment of in vivo photosynthesis. Ecol Stud 100:49-70

- Skene KR (2004) Key differences in photosynthetic characteristics of nine species of intertidal macroalgae are related to their position on the shore. Can J Bot 82:177-184

Smith CM, Alberte RS (1994) Characterization of in vivo absorption features of chlorophyte, phaeophyte and rhodophyte algal species. Mar Biol 118:511-521

Steneck RS, Watling L (1982) Feeding capabilities and limitation of herbivorous mollusks - a functional-group approach. Mar Biol 68:299-319

Stephenson TA, Stephenson A (1972) Life between tidemarks on rocky shores. Freeman, San Francisco, CA

> Tedetti M, Sempéré R (2006) Penetration of ultraviolet radiation in the marine environment. A review. Photochem Photobiol 82:389-397

Underwood AJ (1985) Physical factors and biological interactions: the necessity and nature of ecological experiments. In: Moore PG, Seed R (eds) The ecology of rocky coasts. Hodder \& Stoughton, London, p 372-383

- Wahl M, Molis M, Davis A, Dobretsov S and others (2004) UV effects that come and go: a global comparison of marine benthic community level impacts. Glob Change Biol 10: 1962-1972

> Westermeier R, Gómez I (1996) Biomass, energy contents and major organic compounds in the brown alga Lessonia nigrescens (Laminariales, Phaeophyceae) from Mehuín, south Chile. Bot Mar 39:553-559

> Wiencke C, Roleda MY, Gruber A, Clayton MN, Bischof K (2006) Susceptibility of zoospores to UV radiation determines upper depth distribution limit of Arctic kelps: evidence through field experiments. J Ecol 94:455-463

Submitted: March 12, 2009; Accepted: November 16, 2010

Proofs received from author(s): January 22, 2011 